\section{Battle for youth plan}

\section{Munich}

AT the same time as West German education minister Jürgen Möllemann has become the favourite of science organizations, he has become the bane of the education ministers of the Länder (states) in a simmering territorial dispute. Now he faces an all-out battle to gain support for a programme to support young researchers that could shape research and teaching at West German universities for the next 30 years.

Education had traditionally been a rump ministry when Chancellor Helmut Kohl chose Möllemann (Free Democrat or FDP) for the post in March 1987. When the ministry was created in 1972, the weekly newspaper Die Zeit wrote that if West Germany needed separate ministries for research and education, it should also set up separate ministries for letter post and parcel post. But circumstances besides his own ambitious nature helped Möllemann to overcome these hindrances: the FDP saw in the post a chance to put its liberal programmes across, and the federal budget was beginning to fatten after several lean years.

Möllemann soon realized that there is little for an ambitious education minister to do. His official brief covers just a few areas, including funding of the Deutsche Forschungsgemeinschaft (DFG), and construction at universities. So he began to try to steal areas of authority from other jurisdictions, mainly the Länder and, to a lesser extent, the Research Ministry.

Möllemann's style is to find a topical issue, overcrowding at universities for example, which brought students onto the

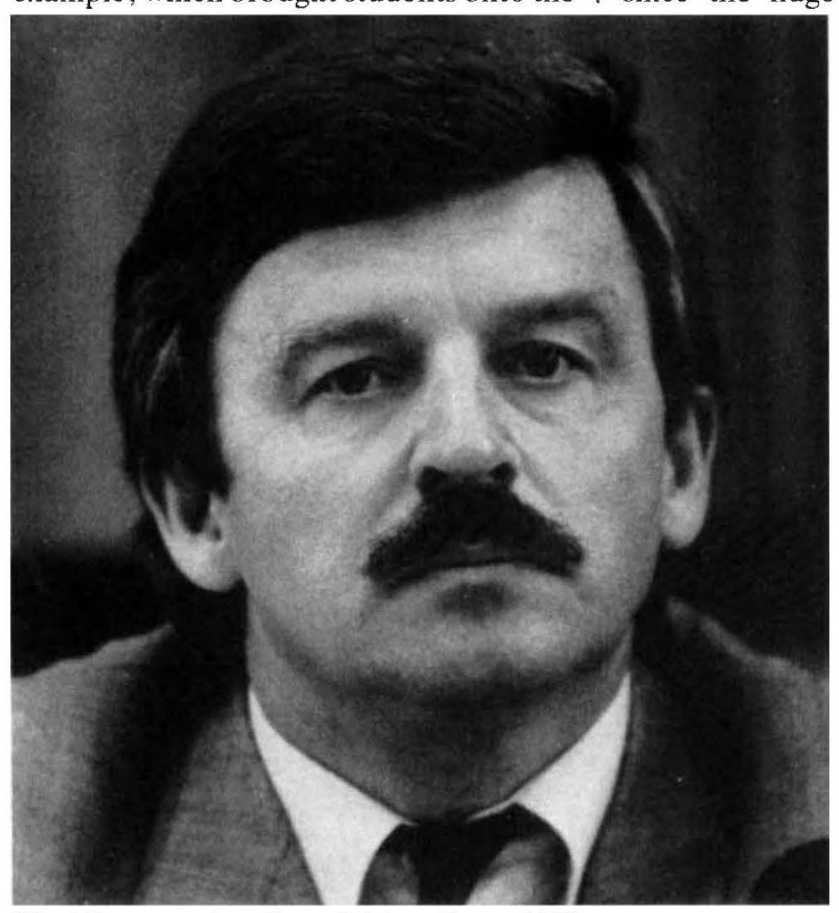

West German education minister, Jürgen Möllemann. streets a year ago in larger numbers than had been seen in 20 years (see Nature 336, $704 ; 1988$ ), then identify himself with the issue in the press - in this case by visiting the Munich university at the height of the unrest, where he was pelted with tomatoes. Finally, he makes a proposal to solve the problem: combined federal and Länder investment to provide more teachers and facilities in overcrowded fields such as business studies.

Möllemann's Staatssekretär Fritz Schaumann lists a number of achievements of which the minister is most proud: an increase in federal aid for students from middle-income families; the establishment of 40-60 graduate colleges to encourage more rapid progression to the $\mathrm{PhD}$ level; support for more research at technical colleges; and big increases in university building funds and for DFG.

For the long-term health of university research and teaching, the most important challenge is the plan to support young researchers for up to ten years until large numbers of professorships become available (see Nature 341, 94; 1989). This could help to persuade the best young people to remain at universities instead of going into industry or business. Despite criticism from finance ministers and even some education ministers in the Länder, the plan still has a fair chance of being passed at a 21 December 'education summit' with Kohl and Länder politicians in Bonn.

But the government will be hard pressed to find the DM6,000 million ( $\$ 3,200$ million) that Möllemann wants for the plan. Priorities in Bonn have shifted since the huge influx of East German refugees began this summer.

Another important task, according to Schaumann, will be smoothing the way for the integration of West German courses of study into the European Communities, a tricky problem complicated by the differences in norms among the Länder, which fear losing autonomy to Brussels as well as to Bonn. Möllemann's activities have disturbed the Länder, to whom education policy is one of the last remaining bastions of power in an increasingly centralized country.

"Compared to what he has promised, the results are meagre", complains Thomas Goppel of the Christian Social Union
(Staatssekretär) in the Bavarian Ministry of Science. "If he wants his programmes to succeed, he should discuss them with us first," says Goppel, "he achieves ten per cent of what he has promised and then sells it as success." And "Möllemann is only interested in headlines", says Uwe Knüpfer of the Social-Democrat-run science ministry in North Rhine-Westphalia: "he ignores issues where behindthe-scenes negotiations would be more helpful than publicity campaigns." Goppel and Knüpfer say that Möllemann has done more for his own career than for students and professors.

But Möllemann has admirers in the science organizations. DFG president Hubert Markl says the minister "should be given credit" for this year's budget increase; Markl's pleading fell on deaf ears in the parliament and the government until Möllemann made DFG an issue. And Dieter Simon, chairman of the Wissenschaftsrat, says Möllemann's concern for science has done a lot of good: "even though his suggestions are not always the best, the fact that he keeps making them is a big help." Even critics such as Goppel agree that Möllemann has given a higher education a "new valuation" in the public mind. But both supporters and critics say that the biggest test for Möllemann - gaining federal and Länder support for his ideas - lies ahead. He cannot afford to walk away empty-handed from the 21 December education summit or the lasting effect of his contribution will, in the words of Knüpfer, "vanish in a puff of smoke".

Steven Dickman

\section{RESEARCH FUNDS}

\section{More money for UK science}

\section{London}

As part of UK Government expenditure plans announced last week, about $£ 60$ million will be added to the science budget for each of the next three years. Of the f61 million added to next years budget, $£ 17$ million is earmarked for the construction of a new research vessel for the British Antartic Survey. Small sums are also allocated to the British Geological Survey, to enable it to set up a National Geological Information Service.

Next year's budget will now be $£ 897$ million, 27 per cent more than was spent in 1988-89. The Advisory Board for the Research Councils, which had been pushing for an even greater increase, will be deciding on how the extra money should be distributed among the research councils.

A simultaneous announcement of extra expenditure on higher education anticipates a predicted increase in the number of extra students. A system of student loans is to be introduced as part of the plan to boost numbers.

Peter Newark 